\title{
THE USE OF DAMAGED SPELEOTHEMS AND IN SITU FAULT DISPLACEMENT MONITORING TO CHARACTERISE ACTIVE TECTONIC STRUCTURES: AN EXAMPLE FROM ZÁPADNÍ CAVE, CZECH REPUBLIC
}

\author{
UPORABA DEFORMIRANIH SIG TER IN SITU MERJENJE \\ PREMIKOV PRELOMOV ZA DOLOČITEV AKTIVNIH \\ TEKTONSKIH STRUKTUR: PRIMER IZ JAME ZÁPADNÍ CAVE, \\ ČEŠKA REPUBLIKA
}

\author{
Miloš BRIESTENSKÝ ${ }^{1 \star}$, Josef STEMBERK ${ }^{1}$, Matt D. ROWBERRY ${ }^{1}$
}

\begin{abstract}
UDC 551.242:551.435.84(437.3)
Miloš Briestenský, Josef Stemberk \& Matt D. Rowberry: The use of damaged speleothems and in situ fault displacement monitoring to characterise active tectonic structures: an example from Západní Cave, Czech Republic

The EU-TecNet fault displacement monitoring network records three-dimensional displacements across specifically selected tectonic structures within the crystalline basement of central Europe. This paper presents a study of recent and active tectonics at Západní Cave in northern Bohemia (Czech Republic). It extends previous geological research by measuring speleothem damage in the cave and monitoring displacements across two fault structures situated within the Lusatian Thrust Zone. The speleothem damage reflects strike-slip displacement trends: the WSW-ENE striking fault is associated with dextral strike-slip displacement while the NNW-SSE striking fault is associated with sinistral strike-slip displacement. These measurements demonstrate that the compressive stress $\sigma 1$ is located in the NW or SE quadrant while the tensile stress $\sigma 3$ is oriented perpendicular to $\sigma 1$, i.e. in the NE or SW quadrant. The in situ fault displacement monitoring has confirmed that movements along the WSW-ENE striking fault reflect dextral strike-slip while movements along the NNW-SSE striking fault reflect sinistral strike-slip. In addition, however, monitoring across the NNW-SSE striking fault has demonstrated relative vertical uplift of the eastern block and, therefore, this fault is characterised by oblique movement trends. The fault displacement monitoring has also shown notable periods of increased geodynamic activity, referred to as pressure pulses, in 2008, 2010-2011, and 2012. The fact that the measured speleothem damage and the results of fault displacement monitoring correspond closely confirms the notion that, at this site, the compressive stress $\sigma 1$ persists in the NW or SE quadrant. The presented results offer an insight into the periodicity of pressure

Izvleček UDK 551.242:551.435.84(437.3) Miloš Briestenský, Josef Stemberk \& Matt D. Rowberry: Uporaba deformiranih sig ter in situ merjenje premikov prelomov za določitev aktivnih tektonskih struktur: primer iz jame Západní Cave, Češka Republika

EU-TecNet projektna mreža spremljanja premikov prelomov beleži tri dimenzionalne premike v izbranih tektonskih strukturah kristalinske osnove osrednje Evrope. Članek predstavlja študijo recentne in aktivne tektonike v jami Západní Cave na severu Češke Republike. Gre za razširitev predhodnih geoloških raziskav $\mathrm{z}$ merjenjem deformacij sige ter za merjenje premikov dveh prelomnih struktur znotraj Lusatian narivne cone. Deformacija sige kaže na zmične premike: prelom v smeri ZJZ-VSV je povezan $\mathrm{z}$ desnim horizontalnim zmikom, medtem ko je prelom v smeri SSZ-JJV povezan z levim horizontalnim zmikom. Premiki kažejo, da se kompresijska napetost $\sigma 1$ nahaja v SZ ali JV kvadrantu, medtem ko je raztezna napetost $\sigma 3$ usmerjena pravokotno na $\sigma 1$, to je v SV ali JZ kvadrantu. In situ spremljanje tektonskih premikov je potrdilo, da premiki ob ZJZ-VSV usmerjenih prelomih kažejo desne zmike, medtem ko premiki ob SSZ-JJV usmerjenih prelomih odražajo leve zmike. Hkrati pa so meritve SSZ-JJV usmerjenih prelomov pokazale relativen vertikalni dvig vzhodnega bloka, kar kaže, da ima prelom poševne premike. Spremljanje premikov ob prelomih je pokazalo tudi izrazita obdobja povečane geodinamične aktivnosti, ki jih imenujemo napetostni pulzi v letih 2008, 2010-2011 in 2012. Značilnosti deformacije sige in rezultati o premikih preloma potrjujejo, da kompresijska napetost $\sigma 1$ na tej lokaciji ostaja v SZ ali JV kvadrantu. Rezultati predstavljajo pogled v obdobja napetostnih pulzov, kar kaže na potrebo po dolgotrajnem monitoring, da bi lahko bolje razumeli geodinamične procese ter hkrati pokazali , da je možno določiti premike, ki nastajajo ob posameznih prelomih na način, ki ga ni mogoče določiti z geodetskimi meritvami s pomočjo GNSS.
\end{abstract}

\footnotetext{
${ }^{1}$ Department of Engineering Geology, Institute of Rock Structure and Mechanics, Academy of Sciences of the Czech Republic, V Holešovičkách 41, 18209 Prague 8, Czech Republic, e-mail: briestensky@irsm.cas.cz; stemberk@irsm.cas.cz; e-mail: rowberry@irsm.cas.cz

* Corresponding author
}

Received/Prejeto: 14.08.2013 
pulses, demonstrate the need for protracted monitoring periods in order to better understanding geodynamic processes, and show that it is possible to characterise the displacements that occur across individual faults in a way that cannot be accomplished from geodetic measurements obtained by Global Navigation Satellite Systems.

Keywords: active tectonics, speleothem damage, fault displacement, stress field, Lusatian Thrust Zone, Západní Cave.
Ključne besede: Aktivna tektonika, deformacija sige, premiki ob prelomu, napetostno polje, Lusatian narivna cona, jama Západní Cave.

\section{INTRODUCTION}

The EU-TecNet fault monitoring network has been recording three-dimensional displacements across specifically selected tectonic structures within the shallow crust for more than a decade (Stemberk et al. 2003; Briestenský et al. 2007; Košták et al. 2011). The network was established to characterise the displacements that occur across individual faults as these cannot be resolved from geodetic measurements obtained by Global Navigation Satellite Systems (GNSS). It currently records displacements across more than one hundred tectonic structures within the crystalline basement of central Europe (EU-TecNet 2013). This intracratonic region is particularly suitable for the study of microdisplacements because the highly fractured crystalline basement is not associated with significant seismic activity (Stemberk et al. 2010).

The relative three-dimensional displacements are measured using specially designed optical-mechanical crack gauges (Košták \& Popp 1966; Košták 1969). These are permanently installed in caves or other underground spaces because such settings are able to preserve a threedimensional record of deformation unaffected by subsequent erosion and they are largely shielded from climatic effects such as diurnal or seasonal massif dilations
(Briestenský et al. 2010, 2011a, b). The data are recorded across the monitoring network once a month due to the fact that the readings have to be taken manually (Klimeš et al. 2012). The network has, nonetheless, demonstrated that underlying tectonic processes are initiated as a result of the widespread redistribution of stress and strain within the crust (Košták et al. 2007; Stemberk et al. 2010; Košták et al. 2011, Briestenský et al. 2014).

This paper presents a study of recent and active tectonics at Západní Cave in northern Bohemia (Czech Republic). It extends previous geological research by measuring speleothem damage in the cave and monitoring displacements across two fault structures located within the Lusatian Thrust Zone. The overall objectives of the paper are to: (i) provide a geological and geomorphological overview of Ještěd Ridge; (ii) provide a detailed geological description of Západní Cave; (iii) present the measurements of speleothem damage in the cave; and (iv) present the results of the displacement monitoring across two faults in the cave. The measurements of speleothem damage and the results of fault displacement monitoring have been used to compute the recent regional stress field.

\section{METHODS}

A number of previous studies have shown that damaged speleothems may be indicative of active tectonics (e.g. Kashima 1993; Gilli 2005; Becker et al. 2012; Camelbeeck et al. 2012). In certain situations within cave systems it is clear that damaged speleothems are associated with fault outcrops (Šebela 2008). At Západní Cave the idea that tectonic activity was responsible for the significant number of fresh speleothem breaks was suggested by their association with the main faults although it was, of course, important to consider other possible mechanisms that may lead to such damage such as freezing, gravita- tional movements, or sediment infill volume changes. The most appropriate places in which to study the speleothems were selected, in so far as is possible, usually in the cave ceiling (Briestenský et al. 2011a). At each location the amount of displacement was recorded along with the displacement vector.

The in situ fault displacements were recorded using two permanently installed optical-mechanical crack gauges. Their ability to record data in three-dimensions is critical as the movement between fault planes is frequently characterised by slip (Košták 2006). These mea- 
sure relative displacement and angular rotation using the moiré phenomenon of optical interference (Oster \& Nishijima 1963). The moiré patterns appear when two identical overlapping periodic structures undergo a small relative displacement causing the development of a series of characteristic macroscopic interference fringes whose arrangement and periodicity does not necessarily resemble that of the overlapping structures (Marti et al. 2013). Its configuration, however, is deterministic and the observed patterns reflect the amount and direction of relative movement (Marti et al. 2013). The gauge itself comprises two pairs of two identical overlapping glass plates referred to as the combined indicator (Košták 1991). The plates are each etched with one spiral grid and two rectangular grids, one horizontal and one vertical (Klimeš et al. 2012).

The moiré interference of two regular Archimedes spirals is represented by a family of hyperbolas with a common principal axis that follows the direction of the displacement. The family comprises a variable number of macroscopic fringes proportional to the amount of relative displacement. Therefore, if the orientation of the principal axis and the number of fringes is known, through a simple trigonometric transformation the amount of relative displacement can be calculated (Košták 1991). The moiré interference of two identical overlapping sets of parallel lines is represented by a family of oblique parallel lines which slope according to the direction of the rotation. The family comprises a variable number of macroscopic fringes whose period is proportional to the amount of relative rotation a (Košták 1991). It is possible to record relative displacements in three co-ordinates $(x, y, z)$ with a precision of better than $\pm 0.007 \mathrm{~mm}$ and horizontal and vertical rotations ( $g x y$ and $g x z$ ) with a precision of better than $\pm 0.00016 \mathrm{rad}$.

\section{THE GEOLOGY AND GEOMORPHOLOGY OF JEŠTĚD RIDGE}

The studied cave is situated within the broad geomorphological unit of the Ještěd-Kozákov Ridge and, more specifically, within the subunit of Ještěd Ridge (Demek 1987). The Ještěd-Kozákov Ridge has a length of almost $60 \mathrm{~km}$ and a width that does not exceed $15 \mathrm{~km}$ and comprises part of the Western Sudetes. It runs from the northwestern hills of Pískový vrch (547 m asl) and Ostrý vrch (514 m asl) to the southeastern hill of Kozákov (744 m asl). The ridge is intersected by the deep valleys of the Mohelka and Jizera Rivers. The highest, and best-known, point along the ridge is the summit of Ještěd (1012 m asl) which overlooks the city of Liberec and which hosts a spectacular hyperboloid television tower. The Ještěd Ridge is a wedge-shaped horst trending NW-SE. It is composed of strongly folded, mainly during the Variscan Orogeny (Chlupáč 1964), slightly to epizonally metamorphosed rocks dating from the late Proterozoic and Paleozoic, which were uplifted during Saxonian movements (Kozdrój et al. 2001). The northeastern part of the horst is separated from the Železný Brod Crystalline Complex, the Variscan granitoids of the Krkonoše Pluton, and the Cambrian-Ordovician Jizera orthogneiss by the NW-SE trending Machnín Fault. The southwestern part of the horst borders the platform sediments of the Bohemian Cretaceous Basin and Mnichovo Hradiště Basin that forms part of South Krkonoše Piedmont Basin. This contact is represented by a wider fault zone, called the Lusa- tian Thrust. This thrust represents the most significant fault zone in the northern part of the Bohemian Massif while it also comprises part of an important feature that crosses much of central Europe (Malkovský 1979). It strikes from Dresden in Germany to Turnov in the Czech Republic with a length more than $110 \mathrm{~km}$ (Malkovský 1977). Its thrust plane dips to the NNE by $15-75^{\circ}$ (Pošmourný 1967; Kurka \& Bělohradský 1979; Coubal et al. 1999). The present position of the crystalline block and platform sediments, which is divided by the Lusatian Thrust (Fig. 1), has resulted from several generations of movement (Coubal 1989). The most recent morphostructural development of Ještěd Ridge began in the Pliocene, with intense activity in the Pleistocene, which is considered to be ongoing (Kopecký 1970). It has been proposed that, since that time, the amplitude of vertical movement has ranged from around $500 \mathrm{~m}$ to $700 \mathrm{~m}$ (Vyskočil \& Kopecký 1974) to perhaps more than $1000 \mathrm{~m}$ (Malkovský 1979). The entire course of the fault is covered by Quaternary sediments and it does not have a morphological expression (Coubal et al. 1999). There are also a number of faults running parallel to the Lusatian Thrust and these separate the Ještěd Crystalline Unit into partial blocks (Fig. 1). The Ještěd Ridge karstic area has developed in WSW-ENE trending strips of metamorphosed Devonian limestones (Chlupáč 1998), most of which have tectonised limits (Kachlík 2002). 


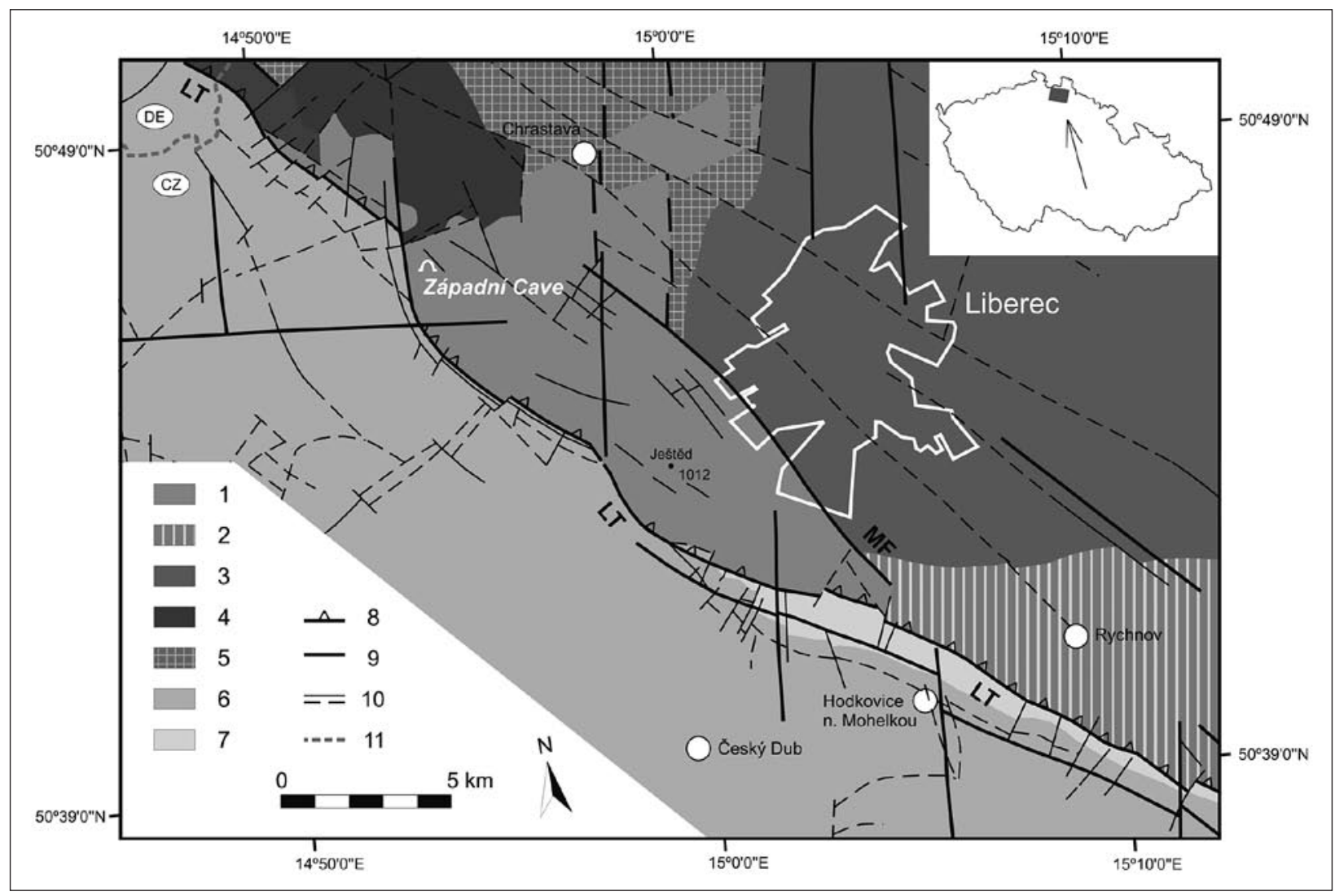

Fig. 1: The geological units and fault systems in the vicinity of Západní Cave (modified after Chaloupský et al. 1989; Kozdrój et al. 2001). Krkonoše-Jizera Crystalline Unit - 1: Ještěd Crystalline Unit; 2: Železný Brod Crystalline Unit; 3: Krkonoše Granites; 4: Lusatian Granodiorite Massif; 5: Jizera Metamorphic Complex; 6: Bohemian Cretaceous Basin. South Krkonoše Piedmont Basin - 7: Mnichovo Hradiště Basin. 8: thrust; 9: main faults; 10: secondary faults (either certain, assumed, or concealed under a sedimentary cover); 11: state boundary. LT: Lusatian Thrust; MF: Machnín Fault.

\section{THE GEOLOGY AND GEOMORPHOLOGY OF ZÁPADNÍ CAVE}

The cave is located within a small body of crystalline limestones in the Ještěd Crystalline Complex approximately $15 \mathrm{~km}$ west of Liberec, close to the village of Jítrava, in northern Bohemia (Fig. 1). This complex forms part of the western sector of the larger KrkonošeJizera Crystalline Unit (Chaloupský et al. 1989). It is the largest cave found within the karstic part of Ještěd Ridge and its entrance is situated in an old limestone quarry on western slope of Vápenný Hill (790 m asl). The quarry represents one of the most important stratigraphic and paleontological localities in the Czech part of the West Sudetes due to its well documented Devonian fauna (Koliha 1929). The beds here form an asymmetrical, almost isoclinal brachyanticline, which is reversed to the SE. The core of the structure consists of black pyrite-bearing phyllitic shales of Lower Fammenian age, overlain by an approximately $20 \mathrm{~m}$-thick bed of crystalline limestones. These limestones were slightly metamorphosed during the Variscan Orogeny. The superincumbent bed is represented by a thick complex of green and grey schists, greywacke, and conglomerate from the Lower Carboniferous (Chlupáč 1964; Budil et al. 1999). The cave has developed along two faults: $80^{\circ} \rightarrow 150^{\circ}$ (dip $\rightarrow$ dip direction) and $70^{\circ} \rightarrow 062^{\circ}$ (Bosák \& Horušický 1978). The NNW-SSE striking fault has the same orientation as the nearby Lusatian Fault (Fig. 1). In total the length of the cave passages attains approximately $280 \mathrm{~m}$ while the denivelation is $25 \mathrm{~m}$ (Hromas et al. 2009). It is divided into two parts: Staré jeskyně Cave, discovered in 1958, and Nové jeskyně Cave, discovered in 1962. Staré jeskyně Cave consists of high, predominately narrow, passages that have developed along fractures. Its main corridor has a length of 
$40 \mathrm{~m}$ and a width of between $0.5-1 \mathrm{~m}$. Nové jeskyně Cave comprises a larger hall that narrows progressively away from the entrance and is occasionally flooded. It hosts an unusual range of cave decorations such as transpar- ent stalactites and excentriques while the cave walls are draped by flowstone. The clastic sedimentary fills consist of loams with gravels and cobbles (Bosák \& Horušický 1978).

\section{RESULTS}

\section{SPELEOTHEM DAMAGE MEASURED ALONG THE TWO MAIN FAULTS}

During our research, which focused on mapping the structural and morphological features of the cave, it was noted that speleothems precipitated along fractures were commonly damaged by fresh cracks and breaks. The damage is clearly associated with both of the aforementioned faults. In those places where the speleothems had not broken completely it could be seen that the displacements were characterised by strike-slip movements (Fig. 2). Moreover, in places where the speleothems were accessible, the displacements could be measured using a slide gauge (Fig. 3). The measured speleothem damage, characterised by strike-slip movements, showed dex- tral strike-slip displacements ranging from $1.24 \mathrm{~mm}$ to $3.40 \mathrm{~mm}$ along the WSW-ENE striking fault and sinistral strike-slip displacements ranging from 4.10 to $5.60 \mathrm{~mm}$ along the NNW-SSE striking fault. On the basis of the results of this survey, the recent local stress field orientation was determined (Jurková \& Briestenský 2008). The observed senses of displacement demonstrates that compressive stress $\sigma_{1}$ is located in the NW or SE quadrant while the tensile stress $\sigma_{3}$ is oriented perpendicular to $\sigma_{1}$, i.e. in the NE or SW quadrant (Fig. 2).

\section{IN SITU FAULT DISPLACEMENT MONITORING}

In 2007, due to the presence of the damaged speleothems and the location of the cave within the Lusatian Thrust

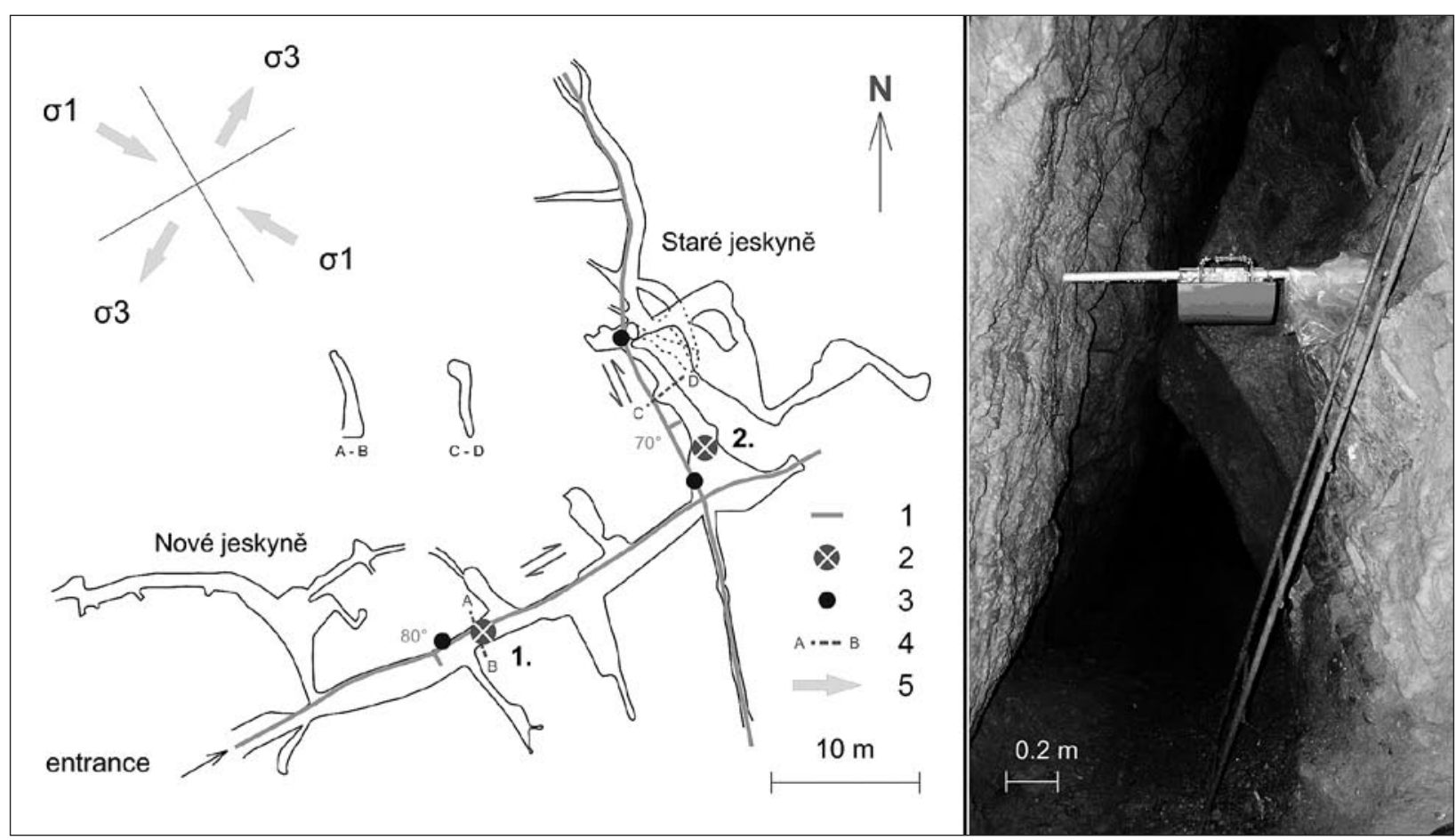

Fig. 2: A sketch of Západní Cave showing the position of damaged speleothems and the location of the two permanently installed optical-mechanical crack gauges (modified after Skrivánek \& Hromas 1961). 1: significant faults with recorded displacement directions indicated by arrows: 2: sites in which the fault displacements are recorded using optical-mechanical crack gauges; 3: sites in which the damaged speleothems have been measured using a slide gauge; 4: space profiles; 5: computed stress directions according to speleothem deformation and fault displacements recorded in the cave. The photograph on the right shows the location of gauge N1 across the WSWENE striking fault, taken from the NE (Photo: T. Nýdl). 
Zone, the authors decided to install two optical-mechanical crack gauges in order to record direct in situ fault displacements. The location of the instruments is shown in Fig. 2. In accordance with the monitoring interval at many of the sites within EU-TecNet fault displacement monitoring network the data have been recorded once a month since May 2007. The results of fault displacement monitoring show significant fault trends at both of the

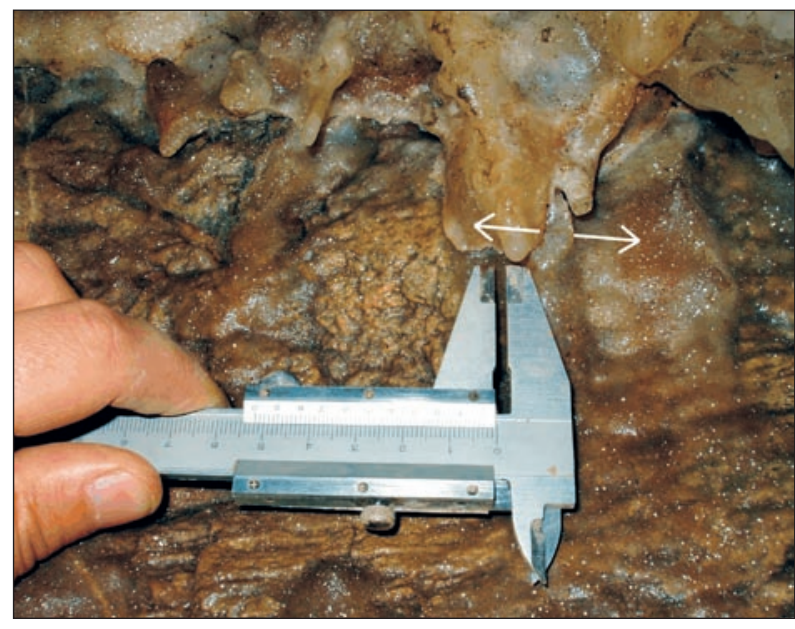

Fig. 3: An example of the speleothem damage measured along the main corridor of the cave. The arrows on the photograph indicate the direction of displacement (Photo: M. Briestenský). monitored sites. The WSW-ENE striking fault records a long-term dextral strike-slip trend of $0.25 \mathrm{~mm}$ over a period of 4.5 years (Site N1, Fig. 2 \& Fig. 4) while the NNWSSE striking fault records long-term uplift of the eastern block of $0.5 \mathrm{~mm}$ over a period of 5.5 years together with a silent sinistral trend of $0.05 \mathrm{~mm}$ over a period of 4.5 years (Site N2, Fig. 2 \& Fig. 4).

The vertical trend that characterises the NNWSSE striking fault $\left(70^{\circ} \rightarrow 062^{\circ}\right)$ demonstrates recent activity on, and the persisting thrusting of, the Lusatian Fault. The fact that the measured speleothem damage and the results of fault displacement monitoring correspond closely confirms the notion that, at this site, the compressive stress $\sigma 1$ persists in the NW or SE quadrant. This regional stress field is consistent with other studies, such as those conducted in western Bohemia, in which a compressive stress orientation of $\sigma_{1}$ in the NW quadrant was also recognised (e.g. Grünthal \& Stromeyer 1992; Wirth et al. 2000). It also supports the notion that, "farther from the Alpine chain, a more consistent direction of compression has dominated first NW-SE, then NNW-SSE" (Bergerat 1987). Therefore, the two methods used in this study deliver similar results, and these are consistent with other models of the regional stress field in central Europe. Although many studies have noted an association between damaged speleothems and active tectonics, until recently comparatively few had been able

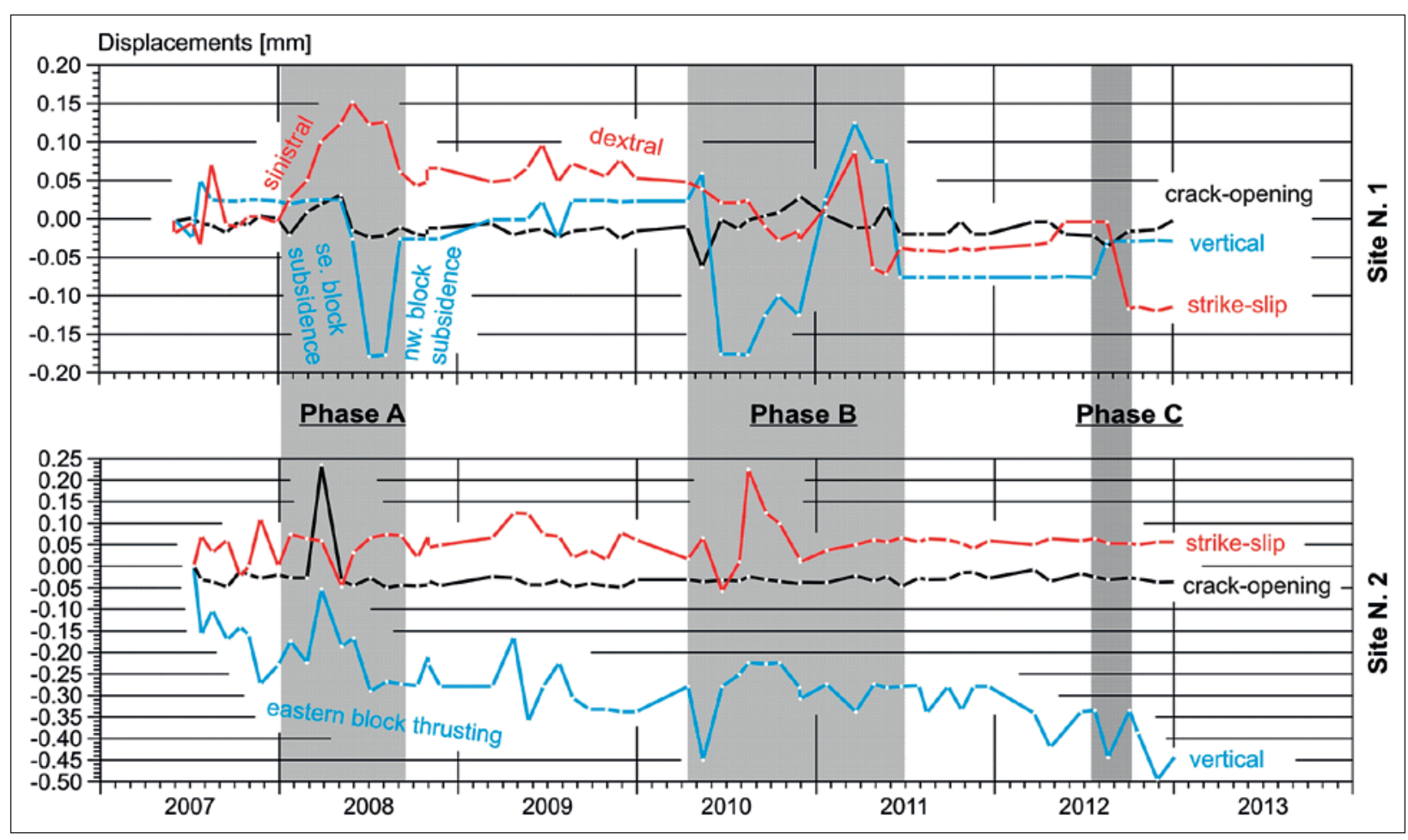

Fig. 4: Fig. 4: The results of in situ fault displacement monitoring obtained using permanently installed optical-mechanical crack gauges located across two faults within Západni Cave. Also marked are the notable pressure pulses recorded in 2008, 2010-2011, and 2012. 


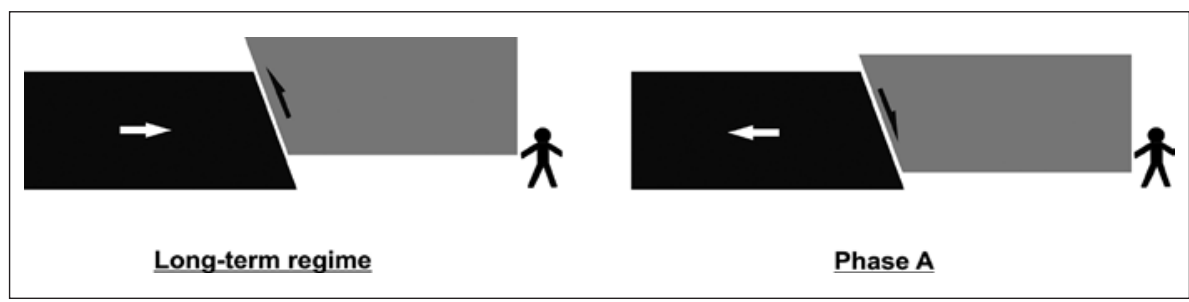

Fig. 5: Schematic models of the displacements recorded across the NNW-SSE striking fault in Západni Cave. Left: the overall results of the long-term monitoring from 2007-2012. Right: the results obtained during the notable pressure pulse in 2008.

to directly relate speleothem damage to direct measurements of fault displacement (Briestenský et al. 2011a; Camelbeeck et al. 2012).

The fault displacement monitoring also shows notable periods of increased geodynamic activity, referred to as pressure pulses, in 2008, 2010-2011, and 2012. These pressure pulses simultaneously interfere with the longterm displacement trends at both sites. Three pulses have been registered since monitoring began in 2007 (Fig. 4 A, B, C). The most susceptible instrument appears to be $\mathrm{N} 1$ as, at this locality, the pressure pulses seem to last for longer periods and induce larger displacement amplitudes. The long-term trend is one of progressive compression as shown by the eastward horizontal shift of the western block and uplift of the eastern block (Fig. 4 \&
Fig. 5 (left)). However, during "Phase A" there is significant fault relaxation, as shown by the westwards horizontal shift of the western block horizontal and subsidence of the eastern block (Fig. 4 \& Fig. 5 (right)).

These three pressure pulses are considered to reflect periods in which there are significant modifications to the stress field. It is clear that the pressure pulses are coeval and, therefore, the displacements cannot be associated with local seismic tremors, neither as co-seismic nor post-seismic processes. This corroborates the previous proposition that the pressure pulses reflect the "slow process of stress/strain transformation that leads to fault displacement and possibly earthquakes" (Stemberk et al. 2010). These pulses may occur prior to earthquake activity, often preceding it by several months. Košták et al. (2011) noted that neither the sources nor the periodicity of the pressure pulses is known. This study offers the first real insight into the latter and demonstrates the value of long-term monitoring in relation to better understanding geodynamic processes.

\section{CONCLUSIONS}

The measured speleothem damage and the results of the in situ fault displacement monitoring within Západní Cave provide evidence for recent and ongoing tectonic movements across two fault structures within the Lusatian Thrust Zone. The measured speleothem damage, characterised by strike-slip movements, shows dextral strike-slip displacements ranging from 1.24 to $3.40 \mathrm{~mm}$ along the WSW-ENE striking fault and sinistral strikeslip displacements ranging from 4.10 to $5.60 \mathrm{~mm}$ along the NNW-SSE striking fault. The compressive stress $\sigma_{1}$ is located in the NW or SE quadrant while the tensile stress $\sigma_{3}$ is oriented perpendicular to $\sigma_{1}$, i.e. in the NE or SW quadrant. The results of fault displacement monitoring show a long-term dextral strike-slip trend of $0.25 \mathrm{~mm}$ over a period of 4.5 years along the WSW-ENE trending fault while the NNW-SSE trending fault presents evidence for uplift of the eastern block $(0.5 \mathrm{~mm}$ over a period of 5.5 years) together with a silent sinistral trend
(0.05 mm over a period of 4.5 years). It is not possible to extrapolate these measurements in order to provide further information about either the origin or development of the cave system due to the fact that displacement trends are known to both oscillate over protracted periods and accelerate during periods of increased geodynamic activity. For example, there are notable periods of increased geodynamic activity in 2008, 2010-2011, and 2012. The fact that the measured speleothem damage and the results of fault displacement monitoring correspond closely confirms the notion that, at this site, the compressive stress $\sigma 1$ persists in the NW or SE quadrant. The presented results demonstrate that it is possible to characterise the displacements that occurs across individual faults in a way that cannot be accomplished from geodetic measurements obtained by Global Navigation Satellite Systems. 


\section{ACKNOWLEDGEMENTS}

The authors wish to acknowledge the financial support provided by the Czech Ministry of Education, Youth, and Sports (COST OC 625.10), the Czech Science Foundation (GA205/05/2770, GA205/06/1828 \& GA205/09/2024), and the Grant Agency of the Academy of Sciences of the
Czech Republic (IAA300120801). The study was conducted within the framework of the research plan for the Institute of Rock Structure and Mechanics ASCR (A VOZ30460519) and CzechGeo/EPOS (Project No. LM2010008).

\section{REFERENCES}

Becker, A., Häuselmann, P., Eikenberg, J. \& E. Gilli, 2012: Active tectonics and earthquake destructions in caves of northern and central Switzerland.- International Journal of Speleology, 41, 1, 35-49.

Bergerat, F., 1987: Stress fields in the European platform at the time of Africa-Eurasia collision.- Tectonics, 6, 2, 99-132.

Bosák, P. \& R. Horušický, 1978: Současný stav výzkumů krasových jevů Ještědského hřbetu [The current state of research into karst phenomena along Ještěd Ridge].- Československý kras, 29, 47-52.

Briestenský, M., Košták, B., Stemberk, J., Petro, L., Vozár, J. \& L. Fojtíková, 2010: Active tectonic fault microdisplacement analyses: a comparison of results from surface and underground monitoring in western Slovakia.- Acta Geodynamica et Geomaterialia, 7, 4, 387-397.

Briestenský, M., Stemberk, J., Michalík, J., Bella, P. \& M.D. Rowberry, 2011a: The use of a karstic cave system in a study of active tectonics: fault movements recorded at Driny Cave, Malé Karpaty Mts (Slovakia).- Journal of Cave and Karst Studies, 73, 2, 114-123.

Briestenský, M., Stemberk, J. \& L. Petro, 2007: Displacements registered around the March $13^{\text {th }} 2006 \mathrm{Vr}$ bové earthquake $\mathrm{M}=3.2$ (Western Carpathians).Geologica Carpathica, 58, 5, 487-493.

Briestenský, M., Thinová, L., Stemberk, J. \& M.D. Rowberry, 2011b: The use of caves as observatories for recent geodynamic activity and radon gas concentrations in the Western Carpathians and Bohemian Massif.- Radiation Protection Dosimetry, 145, 2-3, 166-172.

Briestenský, M., Thinová, L., Praksová, R., Stemberk, J., Rowberry, M.D. \& Z. Knejflová, 2014: Radon, carbon dioxide, and fault displacements in central Europe related to the Tōhoku Earthquake.- Radiation Protection Dosimetry, doi: 10.1093/rpd/ncu090.
Budil, P., Štěpánek, P., Adamovič, J., Coubal, M., Chlupáč, I., Opletal, M. \& J. Valečka, 1999: Examples of important geological localities in the Sudetes (Czech Republic).- Polish Geological Institute Special Papers, 2, 27-32.

Camelbeeck, T., Ruymbeke, M., Quinif, Y., Vandycke, S, Kerchove, E. \& Z. Ping, 2012: Observation and interpretation of fault activity in the Rochefort cave (Belgium).- Tectonophysics, 581, 48-61.

Chaloupský, J. et al. 1989: Geologie Krkonoš a Jizerských hor [Geology of the Krkonoše and Jizerské Mts].Academia, pp. 288, Prague.

Chlupáć, I., 1964: Nový nález fauny ve slabě metamorfovaném paleozoiku Ještědského pohoř́ [New faunal finds in the low-grade metamorphic Paleozoic mountains of Ještěd].- Časopis pro mineralogii a geologii, 9, 1, 27-35.

Chlupáč, I., 1998: Poznámky k rozšíření devonu a stavbě metamorfovaného paleozoika $\mathrm{v}$ jižní a střední části Ještědského pohoří [Notes on the Devonian distribution and structure of metamorphosed Paleozoic rocks in southern and central parts of the Ještěd Mts].- Zprávy o geologických výzkumech $\mathrm{v}$ roce 1997, 19-22.

Coubal, M., 1989: Projevy saxonské tektogeneze v centrální ćásti České krídové pánve [The manifestation of Saxonian tectonics in the central part of the Bohemian Cretaceous Basin].- Manuscript, Archive of Czech Geological Institute, pp. 236, Prague.

Coubal, M., Čech, S., Málek, J. \& V. Prouza, 1999: Lužický zlom.- Závérečná zpráva grantového projektu $G A C \check{R} R$ č. 205/96/1754 [Lusatian Fault - final report of grant project GAČR No. 205/96/1754].- Manuscript, Archive of Czech Geological Institute, Prague.

Demek, J., 1987: Zemépisný lexikon ČSR, hory a níziny [Geographical lexicon of ČSR, mountains and lowlands].- Academia, pp. 584, Prague. 
EU-TecNet, 2013: The EU-TecNet monitoring network TM-71.- [Online] Available from: http://www.irsm. cas.cz/ext/tecnet/index.php [last accessed: 22 November 2013].

Gilli, E., 2005: Review on the use of natural cave speleothems as palaeoseismic or neotectonics indicators.- Comptes Rendus Geosciences, 337, 13, 12081215.

Grünthal, G. \& D. Stromeyer, 1992: The recent crustal stress field in central Europe - trajectories and finite-element modeling.- Journal of Geophysical Research, 97, B8, 11.805-11.820.

Hromas, J. et al. 2009: Jeskyně [Caves].- In: Mackovčin, P. \& M., Sedláček (eds.): Chráněná území ČR [Preserved areas of the Czech Republic].- Agentura ochrany př́rody a krajiny ČR, pp. 608, Prague.

Jurková, N. \& M. Briestenský, 2008: Recent movements along tectonic failures in Západní Cave (Ještěd Ridge, Northern Bohemia).- Slovenský kras, 46/25.

Kachlík, V., 2002: Geologická mapa 1:10 000, list 03-1320 Kryštofovo údolí [Geological map 1:10 000, Sheet No 03-13-20 Kryštofovo údolí].- Manuscript, Archive of Czech Geological Institute, Prague.

Kashima, N., 1993: Fracture of speleothems in Hoshinono-ana Cave, Minami-Daito Island, Okinawa Prefecture, Southwest Japan.- Journal of the Speleological Society of Japan, 18, 33-41.

Klimeš, J., Rowberry, M.D., Blahůt, J., Briestenský, M., Hartvich, F., Košták, B., Rybář, J., Stemberk, J. \& P. Štěpančíková, 2012: The monitoring of slow moving landslides and assessment of stabilisation measures using an optical-mechanical crack gauge.- Landslides, 9, 3, 407-415.

Koliha, J., 1929: Svrchní devon v pohoří Ještědském [Upper Devonian in Ještěd Mountains].- Věstník Státního geologického Ústavu, 5, 268-292.

Kopecký, A., 1970: Neotektonický vývoj severních a severovýchodních Čech [Neotectonic development of northern and northeastern Bohemia].- Věstník Ústředního ústavu geologického, 45, 339-346.

Košták, B., 1969: A new device for in situ movement detection and measurement.- Experimental Mechanics, 9, 8, 374-379.

Košták, B., 1991: Combined indicator using moiré technique.- In: Sorum G. (ed.) Field Measurements in Geomechanics, Proceedings of the $3^{\text {rd }}$ International Symposium on Field Measurements in Geomechan$i c s, 9^{\text {th }}-11^{\text {th }}$ September 1991, Oslo. Balkema, 53-60, Rotterdam.

Košták, B., 2006: Deformation effects in rock massifs and their long-term monitoring.- Quarterly Journal of Engineering Geology and Hydrogeology, 39, 249-258.
Košták, B., Cacoń, S., Dobrev, N.D., Avramova-Tacheva, E., Fecker, E., Kopecký, J., Petro, L., Schweizer, R. \& A.A. Nikonov, 2007: Observations of tectonic microdisplacements in Europe in relation to the Iran 1997 and Turkey 1999 earthquakes.- Izvestiya Physics of the Solid Earth, 43, 6, 503-516.

Košták, B., Mrlina, J., Stemberk, J. \& B. Chán, 2011: Tectonic movements monitored in the Bohemian Massif.- Journal of Geodynamics, 52, 1, 34-44.

Košták, B. \& K. Popp, 1966: Moiré strain gauges.- Strain, $2,2,1-12$.

Kozdrój, W., Krentz, O. \& M. Opletal, 2001: Comments on the geological map Lausitz-Jizera-Krkonoše (without Cenozoic sediments) 1: 100 000. Mit Geologische Karte und Legende.- Sächsisches Landesamt für Umwelt, Landwirtschaft und Geologie, pp. 64, Freiberg.

Kurka, J. \& V. Bělohradský, 1979: Průběh a charakter lužického zlomu mezi obcemi Světlá pod Ještědem a Zdislava [The course and character of the Lusatian Fault between the villages of Světlá pod Ještědem and Zdislava].- Acta Musei Bohemiae Borealis, Scientiae Naturales, 11, 185-196.

Malkovský, M., 1977: Di̊ležité zlomy platformního pokryvu severní části Českého masívu [Significant faults in the platform cover of the northern Bohemian Massif].- Výzkumné práce Ústředního Ústavu Geologického, pp 30, Prague.

Malkovský, M., 1979: Tektogeneze platformního pokryvu Českého masívu [Tectonogenetic platform cover of the Bohemian Massif].- Ústřední ústav geologický, pp. 176, Prague.

Marti, X., Rowberry, M.D. \& J. Blahůt, 2013: A MATLAB code for counting the moiré interference fringes recorded by the optical-mechanical crack gauge TM71.- Computers \& Geosciences, 52, 164-167.

Oster, G. \& Y. Nishijima, 1963: Moiré patterns.- Scientific American, 208, 5, 54-63.

Pošmourný, K., 1967: Geologicko-petrografické poměry krystalinika západní části Ještědského hřbetu [Geological and petrographical situation of the crystalline complex in the western part of Ještěd Ridge].Acta Musei Bohemiae Borealis, Scientiae Naturales, 3, 15-25.

Šebela, S., 2008: Broken speleothems as indicators of tectonic movements.- Acta Carsologica, 37, 52-62.

Skřivánek, F. \& J. Hromas, 1961: Plán Západní jeskyně [Map of Západní Cave].- Archiv Základní Organizace České Speleologické Společnosti 4-01, Liberec. 
Stemberk, J., Košták, B. \& S. Cacoń, 2010: A tectonic pressure pulse and increased geodynamic activity recorded from the long-term monitoring of faults in Europe.- Tectonophysics, 487, 1-12.

Stemberk, J., Košták, B. \& V. Vilímek, 2003: 3D monitoring of active tectonic structures.- Journal of Geodynamics, 36, 1-2, 103-112.
Vyskočil, P. \& A. Kopecký, 1974: Neotectonics and recent crustal movements in the Bohemian Massif.- Výzkumný ústav geodetický, topografický a kartografický (VÚGTK), pp. 179, Prague.

Wirth, W., Plenefisch, T., Klinge, K., Stammler, K. \& D. Seidl, 2000: Focal mechanisms and stress field in the region Vogtland/Western Bohemia.- Studia Geophysica et Geodaetica, 44, 2, 126-141. 